Nabila Vidi Paramestri ${ }^{1}$; Moses Glorino Rumambo Pandin ${ }^{2}$

${ }^{1}$ Fakultas Psikologi, ${ }^{2}$ Fakultas Ilmu Budaya

KAMPUS B, JALAN DHARMAWANGSA DALAM,

AIRLANGGA, KEC. GUBENG, KOTA SURABAYA, JAWA TIMUR 60286

1nabila.vidi.paramestri-2020@psikologi.unair.ac.id dan²moses.glorino@fib.unair.ac.id

\title{
Book Review: Character Education Learning
}

Title: Pembelajaran Pendidikan Karakter; Author: Siti Nur Aidah and Penerbit KBM Indonesia Team; Publisher: Penerbit KBM Indonesia; Edition: First edition, 2020; Pages: 67 pages; ISBN: 978-623-6965-62-7

\section{INTRODUCTION}

As the younger generation, or as people say "millennials", we have to face the changes that are happening because of globalization. The effects of globalization are severe, as there are a lot of social issues that don't stand with Indonesia's identity and are opposites with it. Issues surrounding violence, human rights, immoral acts, corruption, dishonesty, and the collapse of the young generation's noble character continue to adorn the life of the Indonesian nation. This just yet again reminds us how important it is for us to learn about moral character and implement them in our everyday lives to help our generation be the best version of themselves, and for our nation, Indonesia's future. This book review is written to fulfill the end of semester writing assignment for the Indonesian Civics subject. Hopefully, this book review encourages the young generation to improve their qualities and be the best version of themselves for their and the nation's future.

The book was written to reflect on the moral crisis faced by Indonesia's youth generation. This book aims to help teenagers learn and understand more about character education so that they can apply it to their daily lives. This book has many important points regarding character education, and this book underlines especially how teenagers should act according to the identity of our nation. This book is aimed at the young generation of Indonesia who wants to reflect on their behavior, whether their behaviors are ethical in accordance with Pancasila or not. Given the high number of cases of moral crisis in Indonesia today, this book targets teenagers who want to evaluate and improve their quality. By reading and understanding character education, Indonesian youth can then bring Indonesia to a bright future. 
New information presented from the book is how today's globalization has a great influence on the moral crisis that occurred in Indonesia. This book explains how to increase youth awareness of character education to reduce the negative effects caused by globalization. This book was written pretty recently, which explains why the author also highlights current issues related to the character decadence of Indonesian youth. This book review is expected to be a reading reference for the younger generation so that they continue to remember and practice character education in their daily lives.

Keywords: Globalization, Moral Character, Younger Generation

The book Character Education Learning underlines the meaning and the importance of learning different kinds of character and how to implement it to improve the quality of the younger generations resulting in a brighter future for our nation. Nowadays, there are a lot of social/moral issues that happen in Indonesia, and it is so disheartening to see. People, even Indonesian youth, act however they want to without even thinking about the consequences. They're not behaving according to Indonesia's identity because Indonesia's younger generations are experiencing horrible moral degradation. Indonesian young people are supposed to be the future of this nation, but now we can't have expectations for them anymore. This book has everything we need regarding learning moral characters. Hopefully, by reading the book and this book review, it can encourage the young generation to improve themselves.

According to this book, character education is a conscious and planned human effort to educate and empower the potential of learners to build their character so that they can become individuals who benefit themselves and the environment. For the time being, learning and teaching activities in Indonesia already refer to the implementation of character education. But when we talk about character education, parents need to instill it in children from an early age, right? Children's character education reflects the good behaviors and values that children follow, such as religious, honest, tolerant, disciplined, obedient, and orderly nature. Teaching character education to a child should be done by direct practice because most young children still imitate their parent's behavior. Character education in children takes a long time and also starts from parenting habits and patterns, especially parents.

The purpose of character education according to Article 3 of Law No. 20 of 2003 on the National Education System strongly reflects the importance of the younger generation learning 
character education. Through the article, the purpose of character education is to foster the character and personality of a dignified nation. The way that can be done is to develop the potential of the nation's children who are full of the value of piety, physical health, useful science, creative, independent, democratic, and full of responsibility. In addition, there are also sources of values contained in character education, including religion, Pancasila, and culture.

We have mentioned "character education" numerous times, but do we know what the values of character education are? The Indonesian Ministry of National Education presents 18 values instilled in Indonesians to build and strengthen the character of the nation. There might be a lot, but I am also sure that it is for the better future of our nation, to again, improve the character of the younger generation. The first value is a religious value, and it can be done by performing religious obligations and by tolerating people that have different beliefs from us. The values of honesty are values adopted to make young people trustworthy. The value of tolerance, which is the most important value. Indonesia consists of a variety of cultures, races, and religions. Young people need to apply the values of tolerance and respect the differences of religion, ethnicity, opinions, attitudes, and actions of people who are different from them. Disciplinary values, which exhibit orderly behavior and comply with various rules and regulations. The value of hard work, which shows earnest effort in overcoming obstacles and doing something as best as possible. Creative value, the value of thinking and doing something to produce something new. Independent, an attitude that is not easy depends on others.

Democratic values, a way of thinking and behaving that assesses equal rights and obligations of themselves and others. The value of curiosity, an act that seeks to know more about something. The value of nationality and the love of the homeland, which play an important role in our nation's future. The value of nationality and national spirit could be in a form of using and wearing local products in our daily lives. It also comes in the form of appreciating local products. There are a lot of things we can do to contribute to the success and the bright future for this country, it's now up to us whether or not we want to contribute.

The next important thing that we need to discuss is character education in the globalization era. So many alarming social issues are happening. Hate speech is normalized. Information manipulation, the spread of false news happen all the time. Oppression and hatred of other groups became commonplace. It doesn't make sense how over the years, this nation's younger generation's moral character has deteriorated. Value/moral education is indispensable. 
The benefits of character education in the era of globalization itself are very much and great for the life of the nation and the country because of its vital role in shaping the character of citizens based on the ethical and cultural values of the nation.

Now, after reading about character education, of course, we will understand more about the definition, purpose, types, and benefits of character education, right? This book provides excellent and complete knowledge about character education. In addition, this book also provides good insight into the moral crisis in the era of globalization and how to overcome it. Although this book has few pages, it contains a lot of information but is concise and easy to understand, so it would be great for teenagers to read this book as a reference in learning character education. This book reviews the important points of character education that can be learned by teenagers if they read the book. To be able to manifest a more advanced Indonesia, cooperation between the government and citizens is needed. However, society, especially teenagers as the nation's next-generation, is the key to the future progress of the Indonesian nation. This book can be used as a learning resource for future generations, considering how complete the information contained in this book is so that Indonesia can then produce youths who excel in character.

The author discusses the urgency of character-based education in this globalization era due to various worrying social issues that are starting to damage Indonesia's reputation. The author mentioned that character/moral education is needed based on several arguments, as written on page 56, namely the existence of a real and urgent need, the process of transmitting values as a process of civilization, the role of schools as vital moral educators, the existence of a code of ethics in society, the democratic need for moral education, and so on. The moral crisis that occurred today indeed seems to shift the values of Pancasila that have been fought by our nation's heroes. Teenagers act as if they have no basis in behaving.

However, there are also a few weaknesses. The inappropriate grammar is probably the biggest flaw that this book has. There are still many errors in writing according to Indonesian EYD, for example in the use of capital letters. Another drawback may be the problem of overcoming the moral crisis in globalization which has not been discussed in depth. I think the author should correct grammar and writing errors first before publishing this book because mistakes in writing words can interfere with the cohesiveness of the book. Errors in capitalization and spelling errors can cause different meanings to the words written. 


\title{
References
}

1. Aidah, S. N. (2020). Pembelajaran Pendidikan Karakter. Bojonegoro: Penerbit KBM Indonesia.

\author{
About the Book \\ Title : Character Education Learning \\ Author $\quad$ : Siti Nur Aidah and Tim Penerbit KBM Indonesia \\ Publisher : Penerbit KBM Indonesia \\ Edition : First edition (2020) \\ Pages $\quad: 67$ pages \\ ISBN $\quad$ : 978-623-6965-62-7
}

\section{Author's Biography}

Siti Nur Aidah or Aida was born in Tuban on December 29, 1997. Aida is the youngest of three children. In 2020, Aida graduated from Madrasah Ibtidaiyah Teacher Education (PGMI) at Sunan Giri Bojonegoro Institute of Islamic Religion. Aida's hobby is writing poetry. She wrote to vent her heart and feelings. So far, Aida has written 4 poetry anthology books and 151 non-literary book titles. He already has 4 poetry anthology books and 151 non-literary titles. The poetry anthology books include Aku dan Pendidikan, Puisi Kisah yang Kusampaikan, Puisi Sajak Sandiwara, and Puisi Liku Tanpa Ujung. Aida is busy doing tasks from KBM Indonesia Publishers. She became a script editor at KBM Indonesia. 